Matthias Däumer

\title{
Eschatological Relativity. On the Scriptural Undermining of Apocalypses in Jewish Second Temple, Late Antique and Medieval Receptions of the Book of Watchers ${ }^{1}$
}

The First Book of Enoch (third century BCE) is currently placed between apocryphal and canonical status. Its position at the end of the Old Testament mirrors and prefigures the Book of Revelation of the New Testament. The first part of this pentateuch, the Book of Watchers is named after angels who slept with human females, thus creating heroic, but uncontrollable giants. The protagonist Enoch visits the Beyond in order to bring these Watchers' pleas to God - thus creating the starting point of the socalled Jenseitsreisen ("Journeys to the Beyond"). While the genre of Jenseitsreisen had its heyday in the high Middle Ages, the Book of Watchers is believed to have been unknown at the time, only to reappear in the fifteenth century CE in a version written in an Old-Ethiopian language. In my contribution to the volume, I wish to suggest another theory of reception. My aim is to show how the plot of the Book of Watchers was included in chronological religious material up to the thirteenth century CE, creating a long durée narrative about a culture, writing tradition and way of thinking that is subversive to salvific history and its dogmatic eschatology.

If the languages were already differentiated after Noah, why not before? It is a chink in the armour of the myth of Babel.

Umberto Eco, The Search for the Perfect Language 2

Sometimes when people piss me off,

I ask myself, "What would God do?"

... Then I try to drown them.

The Godless and Irreligious Facebook group ${ }^{3}$

\section{Enoch, the Prediluvian Scribe}

The Ethiopian or First Book of Enoch is currently placed between apocryphal and canonical status. The reason for this ambiguity is that it was not acknowledged by

1 Luckily, no one has to write alone; there are always partners in sacrilege. That is why, for corrections and helpful suggestions to this article, I would like to thank: Daniel McDonald, Matthias Meyer, Justin Vollmann, Christian Zolles and Lena Zudrell.

2 Eco, The Search for the Perfect Language, 10.

3 Meme posted by funnyatheism/fb, April 15, 2017.

๖ Open Access. (c) 2020 Matthias Däumer, published by De Gruyter. (๕) BY-Nc-ND This work is licensed under the Creative Commons Attribution-NonCommercial-NoDerivatives 4.0 License.

https://doi.org/10.1515/10.1515/9783110597745-009 
the Eastern and Western Catholic Church, ${ }^{4}$ but included at the end of the Old Testament in the Bible of the Orthodox Ethiopian Church. In this position at the rear of the Old Testament, the First Book of Enoch mirrors and prefigures the Book of Revelation of the New Testament. Structurally mirroring Moses' Pentateuch, the contemporary form consists of five parts: (1) The Book of Watchers (1 Enoch 1-36), (2b) The Book of Parables (1 Enoch 37-71), (3) The Astronomical Book (1 Enoch 72-82) (4) The Book of Dream Visions (1 Enoch 83-90), and (5) The Epistle of Enoch (1 Enoch 91108). For a long time, the only manuscripts transmitting the text were written in the fifteenth-century Old-Ethiopian language Ge'ez. In 1952, however, archeological findings in the Qumran caves showed that the original Book of Enoch has to be dated back to the Second Temple era, with some of the texts being as old as the third century BCE. The oldest Aramaic texts are those of the Book of Watchers, which in the original Enoch-pentateuch was followed by (2a) The Book of Giants, presumably of similar age. In Christian times, supposedly in the first century CE, ${ }^{5}$ the Book of Giants was replaced by the Book of Parables, an "allusive retelling" 6 of the Book of Watchers. Along with fragments of all parts of the original Enoch-pentateuch, there were other findings in Qumran that Florentino García Martínez collected as the so-called Book of Noah. ${ }^{7}$ Only nine short fragments of this book exist, but they are closely linked to the original Watchers/Giants-plot.

The Book of Watchers is named after angels - former watchers of heaven and sentinels stationed to guard the earthly paradise - who slept with human females, thus creating heroic but uncontrollable giants. These are the Nephilim (הנפלים) of the Torah:

(1) And it came to pass, when men began to multiply on the face of the earth, and daughters were born unto them, (2) that the sons of God saw the daughters of men that they were fair; and they took them wives of all which they chose. [...] (4) There were giants in the earth in those days; and also after that, when the sons of God came in unto the daughters of men, and they bore children to them, the same became mighty men which were of old, men of renown. (5) And God saw that the wickedness of man was great in the earth, and that every imagination of the thoughts of his heart was only evil continually. (6) And it repented the LORD that he had made man on the earth, and it grieved him at his heart. (7) And the LORD said, I will destroy man whom I have created from the face of the earth; both man, and beast, and the creeping thing, and the fowls of the air; for it repenteth me that I have made them. ${ }^{8}$

Equivalent to Genesis, God in the Book of Enoch destroys the children of the Watchers by drowning them in the Deluge. An otherworldly place of penalty for the angels

4 For the most relevant texts leading to this refusal, especially the Augustinian ones, see Charles, "Introduction."

5 Nickelsburg, Jewish Literature Between the Bible and the Mishnah, 254-256; Knibb, “The Date of the Parables of Enoch."

6 Himmelfarb, Ascent to Heaven in Jewish and Christian Apocalypses, 59.

7 The Dead Sea Scrolls, ed. García Martínez, 263-264.

8 Genesis 6:1-7; King James Bible. 
is installed - but not yet inhabited. ${ }^{9}$ The Book of Watchers tells the story of how Enoch becomes the middleman between the condemned and God, travelling through the Beyond to seek forgiveness, first for the angels. As far as one can reconstruct the plot of the Book of Giants, Enoch does the same for their children, the Nephilim. Regarding this aspect, the Watchers/Giants-complex is a twofold eschatology: on the one hand, Enoch sees pictures of the Last Days during his otherworldly journeys (Jenseitsreisen); ${ }^{10}$ on the other, the plot itself culminates in the Deluge, the first apocalypse that wiped out a corrupted creation in a prefiguration of the final Judgement Day.

Enoch is Noah's great-great-grandson, the protagonist and (for most parts) firstperson narrator of this text. At the beginning of the text, he is given two different mandates: first, he is asked by a godly authority to tell the Watchers of their condemnation; second, these Watchers ask Enoch to travel to the Beyond in order to plead for God's forgiveness. The decision to choose Enoch as twofold middleman is well reasoned:

(1) And before everything Enoch had been hidden, and none of the sons of man knew where he was hidden, or where he was, or what had happened. (2) And all his doings (were) with the Holy Ones and with the Watchers in his days. (3) And I Enoch was blessing the Great Lord and the King of Eternity, and behold the Watchers of Heaven called to me, Enoch the scribe, [or: called me "Enoch the Scribe"; M. D.] and [they: the Holy Ones; M. D.] $]^{11}$ said to me: (4) 'Enoch,

9 At this place of penalty, Enoch only sees captivated stars, substitutes for the yet to be punished Watchers. The time at which the Watchers will be taken to their torture is unclear. It is even possible to imagine them still on earth. For this, see Däumer, “'[Er] bezeugte gegen sie alle [...] - und schrieb das Ganze."”

10 The Jenseitsreisen ("Journeys to the Beyond") are the core of the so called Visionsliteratur ("vision literature") that Peter Dinzelbacher described as an important sub-group of late-antique and medieval literature (see Dinzelbacher, Vision und Visionsliteratur im Mittelalter; Dinzelbacher, "Einführung"). Benz, Gesicht und Schrift, showed just recently that it is much easier to treat Jenseitsreisen as a separate genre, for there are enough markers to prove their autonomy as a strongly contoured group of texts. In Benz's study, the Book of Watchers marks the starting point of this enduring genre, reaching from the Second Temple era up to its most famous late-medieval exponent, Dante's Commedia (1307-1321). For the genre of Jenseitsreisen, see also Däumer, "Vision."

11 The identification of the pronouns referred to in 12:3 is problematic. There is certainly a second pronoun, which is understood by most translators to refer to the Watchers (for a second English translation in that manner, see The Book of Enoch or 1 Enoch, trans. Charles, 27-28). Yet a reading that sees the Watchers as the speakers of the following words makes no sense, because they are not very likely to be the ones telling Enoch to condemn them. That is why there has to be a pronominal change between the act in indirect speech of calling Enoch "the Scribe", and the act in direct speech of the condemnation. The German translator Andreas Gottlieb Hoffman writes "Und siehe! die Wächter nannten mich Henoch, den Schreiber. Dann sagte er zu mir: [...]" (Das Buch Henoch, trans. Hoffmann, 9; accentuation: M.D.), thus implicating a speech by God or probably one of his messenger angels. For me it seems far more reasonable to see the Holy Ones of 12:2 as the speakers of the condemnation, as they are the second group that Enoch spends his time with during his retreat. This is in agreement with the most recent German translation by Siegfried Uhlig, which leaves open the grammatical possibility that the pronoun refers to the Holy Ones: "und siehe, die Wächter riefen 
scribe of righteousness, go, inform the Watchers of Heaven who left the high heaven and the eternal place, and have corrupted themselves with the women, and have done as sons of men do, and have taken wives for themselves, and have become completely corrupt on the earth. (5) They will have on earth neither peace nor forgiveness of sin (6) for they will not rejoice in their sons. The slaughter of their beloved ones they will see, and over the destruction of their sons they will lament and petition forever. But they will have neither mercy nor peace. ${ }^{, 12}$

Between 1 Enoch 12:2 and 12:3, the mode of narration changes from third- to firstperson, just at the moment when Enoch is called "the Scribe". There is a certain metanarrative logic to this change, as Enoch can only be the writer of his own words after he has been declared a scribe. Still, this declaration concerns more than just Enoch's vocation to be a legitimate first-person narrator. Later, the semi-magical power of writing enables Enoch to cross the transcendent border: he writes down the pleas of the Watchers and then reads them aloud at the river Dan, where he falls asleep and is lifted to heaven (1 Enoch 13:7-8): Enoch's ability to write is his key to the Beyond and therefore essential for his second mandate, begging for mercy in the name of the Watchers.

Nevertheless, one might ask: why is Enoch (and only Enoch) able to write in the first place and who taught him to write? The text of 12:3 is not clear about that. It can be read as "[T] he Watchers of heaven called to me, Enoch the scribe", ${ }^{13}$ meaning that God made Enoch the first scribe of men and that he is addressed by the condemned angels according to his God-given function. The other interpretation is: "[T]he Watchers of heaven called me 'Enoch the Scribe", meaning that the Watchers conferred upon Enoch the title of "Scribe" via a performative speech act. Seen in this way, the Watchers have taught Enoch the art of writing and are now declaring his education to be finished in giving him this approbation. That would also explain what "doings [he had] [...] with the Watchers" before they summoned him to be their defence lawyer in the Beyond.

Looking at the description of the Watchers' sin, a strong argument for prioritising the second interpretation (i.e. the recognition of the condemned angels as

mich, Henoch den Schreiber, und sie sprachen zu mir: [...]” (Das äthiopische Henochbuch, trans. Uhlig, 533-34; accentuation: M. D.). Another possibility would be George W.E. Nickelsburg's approach, which sees two different groups of watchers between the indirect and the direct speech: "And behold, the watchers of the Great Holy One called me, Enoch the scribe, and said to me, 'Enoch, righteous scribe, go and say to the watchers of heaven [...] , [y] ou will have no peace or forgiveness."' (Nickelsburg, 1 Enoch 1, 234) This seems to be grammatically possible, but, considered from a narratological point, it strikes one as weird that a narrator who has just introduced a group of condemned angels named Watchers should contrast them with heavenly creatures that are also called Watchers. This would mean that the heavenly angels would be the "Watchers of the Great Holy One" and the ones living on earth the "Watchers of Heaven". Despite the hermeneutics of the lectio difficilior, this seems to me to be completely counter-intuitive - even for a text that is more than 2300 years old.

121 Enoch 12:1-6. The Ethiopic Book of Enoch, trans. Knibb, 92.

13 My accentuation; The Ethiopic Book of Enoch, trans. Knibb, 92. 
Enoch's teachers) can be found. In contrast to the plot of Genesis, the Book of Watchers portrays their sin as being not only sexual in nature - indeed, it is analogue to that committed by Prometheus in Greek myth: ${ }^{14}$ the Watchers are condemned for the things they taught mankind without God's consent.

The list of this forbidden knowledge includes many skills that are clearly damnable: the knowledge to forge both weapons (signifying warfare), and jewellery (signifying vanity) as well as the art of colouring the eyes (signifying prostitution 1 Enoch 8:1-2). Beside these skills, there are also elements of intellectual knowledge that are difficult to translate from the Ge'ez. Translation is further confounded by the fact that the relevant fragment of the original text $\left(4 \mathrm{QEnoch}{ }^{\mathrm{b}}\left[4 \mathrm{Q} 202,4 \mathrm{QEn} \mathrm{n}^{\mathrm{b}}\right.\right.$ ar], Col. III) $)^{15}$ - like most of the Qumran findings - is heavily deteriorated.

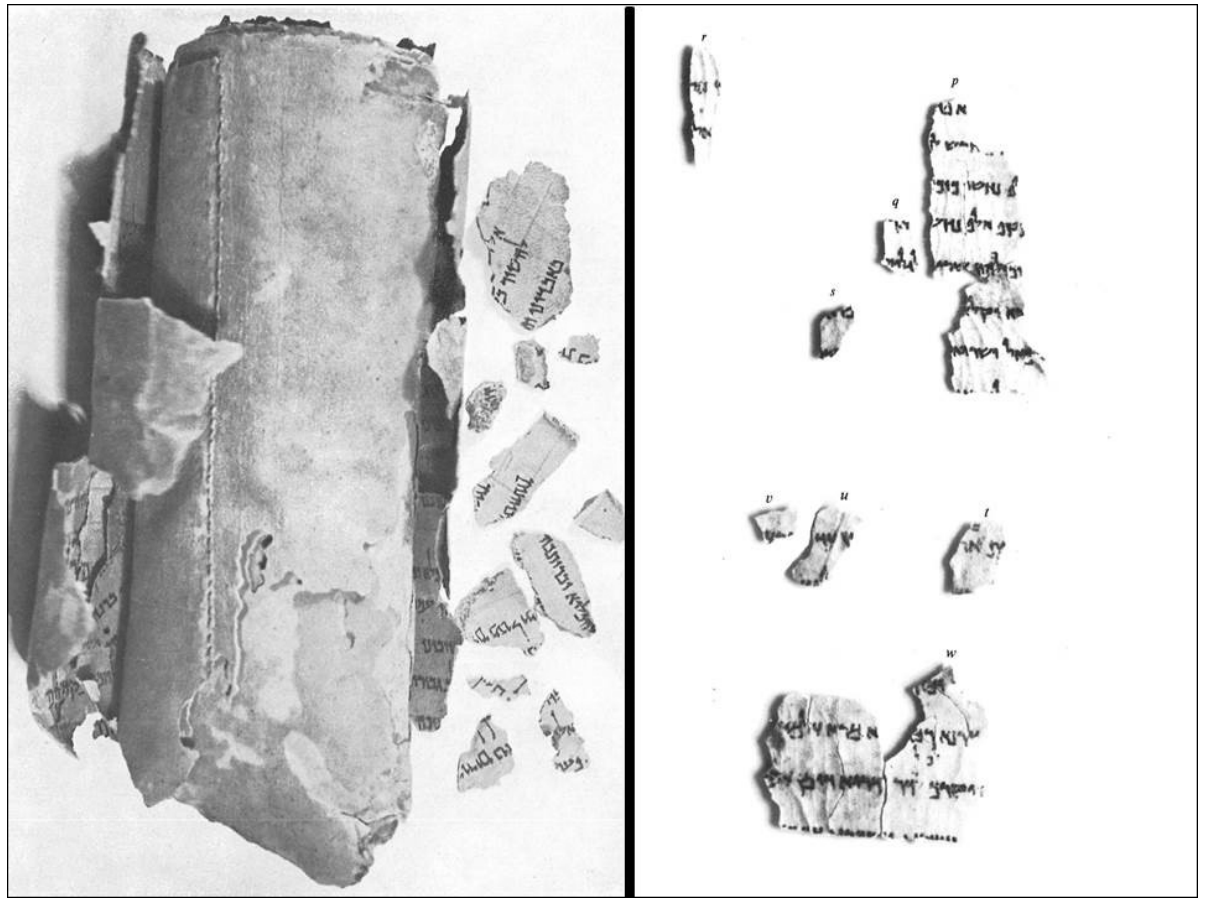

Fig. 1 left: Qumran scroll in early stage of unrolling; right: 4 QEnoch ${ }^{\mathrm{b}}$, Col. III, $1-16^{16}$

14 "The oldest version of the [Prometheus] story is found in works of Hesiod (Theogony, 507-616; Works and Days, 42-105)" (Nickelsburg, 1 Enoch 1, 192-193) that date to before 700 BCE. 15 All editions of the Qumran texts have different systems to name the fragments. I give all the designations according to the format "(ed. Martínez [ed. Maier, ed. Milik])".

16 Left illustration from The Dead Sea Scrolls of the Hebrew University, ed. Sukenik, fig. 13; right illustration from The Books of Enoch. Aramaic fragments of Qumrân Cave 4, ed. Milik, plate VII and VIII. 
In the list of forbidden gifts brought by the Watchers there is a Ge'ez word that basically means "characters/symbols/signs". The Qumran fragments of 4QEnoch ${ }^{\mathrm{b}}$, Col. III retain parts of this original list as well as the direct textual surroundings, but have a gap where the original word for these "characters/symbols/signs" would be. Knibb interpolates "portents", referring to a Greek version of the text, dating from the sixth century CE. ${ }^{17}$ The German translator Siegfried Uhlig is more careful and uses the neutral term Zeichen and merely assumes vielleicht Sternendeutung - "probably astrology". ${ }^{18}$ In his commentary on the Book of Enoch, George W.E. Nickelsburg finally proposes that the original list had been formulaic in the style of "\{name of the Watcher $\}$ taught the signs of $\{\mathrm{X}\}$ ", reducing the "characters/symbols/signs" to a mere introductory element to the astronomical skills. ${ }^{19}$ Combined, however, with the less obscure passages which show that Enoch was personally educated by the Watchers and most probably taught the art of writing, it seems much more reasonable to read the "characters/symbols/signs" in the list of forbidden gifts as "scriptural characters". Following this lead, the fire that the Promethean Watchers brought to earth was the dangerous ability to write.

The early Book of Watchers reception - documents that are much older than the Greek version that lead to Knibb's reading - proves that the semantically narrow translation as "scriptural characters" is valid. The strongest indications in support of Enoch having received writing lessons from the condemned angels are found in the so-called Book of Jubilees, only around 150 years younger than the Book of Watchers itself and also part of the Qumran findings: ${ }^{20}$

(17) And he [Enoch; M. D.] was the first among men that are born on earth who learnt writing and knowledge and wisdom and who wrote down the signs of heaven according to the order of their months in a book that men might know the seasons of the years according to the order of their separate months. (18) And he was the first to write a testimony, and he testified to the sons of men among the generations of the earth[.] $]^{21}$

Enoch is portrayed as the first scribe and astronomer, with his knowledge of the stars being a result of the skill of writing. As the Book of Enoch (especially the Book of Astronomy) was the most important astronomical work of its time, it is also very probable to assume that the book referred to towards the end of this passage means

17 The Ethiopic Book of Enoch, trans. Knibb, 17.

18 Das äthiopische Henochbuch, trans. Uhlig, 522. See 1 Enoch 8,6 in Buch Henoch, trans. Hoffmann, 9, where it is also translated as "Zeichen".

19 Nickelsburg, 1 Enoch 1, 199. Already translated in a similar way in Books of Enoch, ed. Milik, 171 and The Dead Sea Scrolls Translated. The Qumran Texts in English, ed. and trans. García Martínez; trans. Watson. 249.

20 The Dead Sea Scrolls Translated, ed. and trans. García Martínez, 238-245.

21 Jubilees 4:17-18. The Book of Jubilees, trans. Charles, 53. See also 11QJubilees [11Q12, 11QJub], Frag. 3: "(1) [in the fifth wee]k [of the fourth year of the Jubilee and called him Enoch] (2) He was the first (person) [to learn writing”] (The Dead Sea Scrolls Translated, ed. and trans. García Martínez, 241). 
the Book of Enoch itself, showing that Enoch's education was, in fact, considered to be the precondition for the text's very existence.

This precondition is ultimately the crux of the matter. If scriptural characters were part of the forbidden gifts the Watchers brought to earth, and the Book of Enoch was written by Enoch in these sinful characters, then the logical consequence is a major moral problem concerning the text itself, for it is a religious text that declares itself to be predicated upon sin. In addition, as all of Judeo-Christian religion is conditioned by sin, it tells the story of a corrupted medium, of script being the transmitter of a sinfulness that is based on but culturally more elaborate than that of Adam and Eve.

Arriving at this point does not imply a modern, overly-sceptical, non-mythical and thus ahistorical logic - especially since the semi-biblical Book of Enoch is aware of its own problematic status. In the Ge'ez Book of Parables - the replacement for The Book of Giants in the present Enoch-pentateuch - the moral implications of the sinful script taught by the condemned angels are made explicit:

(8) And the fourth [Watcher; M. D.] (is) Penemue: this one showed them all the secrets of their wisdom. (9) He taught men the art of writing with ink and paper, and through this many have gone astray from eternity to eternity, and to this day (10) for men were not created for this, that they should confirm their faith like this with pen and ink. (11) For men were created no differently from the angels, that they might remain righteous and pure, and death, which destroys everything, would not have touched them; but through this knowledge of theirs they are being destroyed, and through this power it (death) is consuming me. ${ }^{22}$

In this retelling of the Watcher plot, the bringing of a sinful script to earth by the Watchers is outlined as fact. Furthermore, it is told in the words of the first-person narrator, Enoch, who describes the use of the Watchers' script as the reason why death came to earth - which again comes close to the committing of the original sin. It will be death - in the form of the Deluge - that consumes all humankind and among them the narrator himself, who at this point cannot know that he (according to Gen. 5:21-24) will be gathered to heaven while still in his body and thus never experience this punishment. ${ }^{23}$ At this point, Enoch - in accordance with the pseudepigraphical status of the text and thus with the limitations of a first-person narrator - seems to be entangled in the snares of his own text, intertwined with scripture, and therefore intertwined with sin. It is a sin that is even more severe for Enoch, since his name, חָכוך] (chanoch), means "the experienced, the profound, the teacher". ${ }^{24}$ As a matter of fact, Enoch was the first human being who was taught the sinful art of writing by the condemned angels, and - very much like the source of an infection - spread this Promethean fire amongst prediluvian humankind. In

221 Enoch 69:8-11. The Ethiopic Book of Enoch, trans. Knibb, 161.

23 According to the Midrashim, Enoch will become Enoch-Metatron, Metatron being his name as "Prince of the World", after his non-death. Bin Gorion, Die Sagen der Juden, ed. Gorion, 125.

24 Von Ranke Graves and Patai, Hebräische Mythologie, 132. 
other words: in the Book of Watchers, Enoch is the promoter of the first apocalypse, although, according to Genesis, he is the one who got away.

\section{The Scriptural Undermining of the Deluge...}

\section{1 ...in the Qumran Fragments}

Both Enoch's ability to write and the fact that he has written the original First Book of Enoch are marked by sin. As a result, it is no surprise that we can find traces in the fragments of the Book of Giants that tell us of God's plan to douse this fiery scripture along with everything in the Deluge:

(1) The book [...] (2) Blank ... (3) Copy the second tablet of the l[etter ...] (4) written by the hand of Enoch, the celebrated scribe

(1) [... and] they washed the tablet to er[ase ...] (2) [...] and the water rose above the [tab]let [...]

(3) $[\ldots]$ and they lifted the tablet from the water, the tablet which [...] (4) [...] ... [...] to them all $[\ldots]^{25}$

It is hard to be certain about the exact sequence of actions, but one can nonetheless grasp that the extinction of the Watchers' sons involves erasing Enoch's writings from the artefact upon which they were inscribed. It is impossible to tell what happened to the tablets if we rely on the Book of Giants exclusively - only the phrase "and they lifted the tablet from the water" seems to indicate that the destruction was prevented, or at least that someone tried to prevent it. That said, other texts of the Qumran Enoch-complex might help solve this riddle. The fragments of the Book of $\mathrm{Noah}^{26}$ tell of the re-establishment of human culture after the Deluge. The astonishing characteristic of this re-establishment is that it seems to be closely linked to the Watchers' sinful deed of original cultural endowment before the Flood:

(14) The waters will cease [...] they will destroy from the high places; all of them will come (15) ... [...] (16) [...] ... [...] and all of [th]em will be rebuilt. His deed will be like that of the Watchers.

(17) Instead of his voice [...] they will establish his foundation upon him. Its sin and [its] gu[ilt] ${ }^{27}$

It is not clear, who "he" is; the only thing certain is that he delivers a sinful and guilt-stained foundation to the new, insufficiently cleansed human culture. "He", the vice-Prometheus, plants a second nucleus of evil in the same way the Watchers

25 4QBook of Ginatsa [4Q203, $1 \mathrm{Q}$ EnGiantsa ar]; The Dead Sea Scrolls Translated, and trans. ed. García Martínez, 260, and 2Q26 [2QEnGiants ar]; The Dead Sea Scrolls Study Edition, eds. Garciá Martínez and Tigchelaar, 221.

26 The Dead Sea Scrolls Translated, ed. García Martínez, 263-264.

27 4Q534 [4QNoah ar], col. II; The Dead Sea Scrolls Study Edition, eds. García Martínez and Tigchelaar, 1071-1073. 
did. It is possible that the sinful protagonist of this text is one of Noah's sons, for there is another fragment that describes Noah's knowledge of "three books" - most probably parts of the pentateuch created by his great-great-grandfather Enoch. These books seem to be the cardinal point of a prophecy of someone who will be empowered to cross over to the Beyond, just like Enoch's writing enabled him to journey to the Beyond:

(4) In his youth he will be ... [... like a m]an who knows nothi[ng, until] the moment in which

(5) [he will] know the three books. Blank (6) Then he will acquire wisdom and will know ... [...]

... of visions, in order to reach the upper sphere. ${ }^{28}$

Besides, this fragment also shows that the already mentioned connection of script and transcendent threshold-crossing has not disappeared, but instead lies dormant until the prophesied gets hold of Enoch's books. By the logic of salvific history, the dormant power of this script has to lead to a second (relative) apocalypse, which, following the narrative of Genesis, is the confusio linguarum caused by the tower of Babel (Gen. 15:5-8).

Umberto Eco sees the Babylonian confusio linguarum as the starting point and main motivator of Europe's Search for the Perfect Language. ${ }^{29}$ This search starts with the feeling of loss that the myth of Babel implicates - the loss of the universal language that Eve and Adam spoke in Paradise. With knowledge of the Watchers/Giants-complex, however, the route from the language of Paradise to the Babylonian Confusion is not a direct one, and the destruction of human communication is not limited to spoken language: before the confusio linguarum there had been a pernicies scripti. This also gives an answer to Eco's bewilderment about the "chink in the armour of the myth of Babel". ${ }^{30}$ The differentiation of languages that already existed in the generation of Noah (see Gen. 10:31-32) seems to weaken the significance of the confusio linguarum. But the point is that it coexists with a unified mode of writing. The Enochian script had survived the Deluge against God's will, and had to be scattered in a second apocalyptical step.

There is, of course, a problem concerning the media at hand, as the Enochian heritage is written language while the story of Babel deals with the spoken word. Yet it seems that one is metonymically connected to the other; while the Babylonian destruction of the universal spoken language is absolute, a scriptural language, like the Watchers brought to earth, is more resilient and able to create artefacts that can be found in later times. Thus, it will always be able to cause a revival or re-infection of the latent spoken word. The difference in medium is mainly a question of poten-

28 4Q534 [4QNoah ar], col. I; The Dead Sea Scrolls Study Edition, eds. García Martínez and Tigchelaar, 1071.

29 Eco, The Search for the Perfect Language.

30 Eco, The Search for the Perfect Language, 10. 
tial endurance: Babel shows that the spoken language is not able to endure, whereas the written word does.

And so, the story of Enoch's writings continues, even after this second major cultural caesura. Enoch's books re-appear in Qumran fragments of a Genesis apocryphon concerning Abram's exile in Egypt. Here, we can be absolutely sure that Enoch's writings survived the fall of the tower, as well as the Deluge:

(23) [...] After these five years (24) three men of the princes of Egypt [came...] from Pharaoh Zoan on account of my [Abram's; M. D.] [words] and of my wife. They gave me (25) [many presents expecting from me] goodness, wisdom and truth. I read in front of them the [book] of the words of Enoch. ${ }^{31}$

The first post-Babel protagonist, Abram (only after Isaac's birth will he be called Abraham), is known in Egypt for his wisdom and the beauty of his wife Sarai (later: Sarah). In response to the Pharaoh's demand to prove his wisdom, Abram does not speak his own words, but reads from the Book of Enoch. Sarai's beauty will lead to her abduction by Pharaoh Zoan, as told in Gen. 12:10-20. The reading of Enoch's words leads to their dissemination in North Africa, thus creating a kind of provenance myth for the lasting importance of the Book of Enoch in the Orthodox Ethiopian Church. It is proof that Enoch's books are highly valued by post-diluvian mankind, and that their auratic power seems to be unbroken despite the confusio linguarum. The second step of the relative apocalypse - relative, as it just almost wipes out human culture, but also relative as in relation to the absolute Apocalypse - seems to have been as inefficient as the first one when it comes to destroying the enduring power of Enoch's writing.

Also, the implications of this endurance cannot be underestimated on an eschatological scale. The reappearance of Enoch's books in the Qumran fragments uncovers a general will to be affiliated with the prediluvian culture through the power of a script whose existence defies the will of God. Both God-willed caesurae, the Deluge as well as the confusio linguarum, were not taken as absolute by writers and collectors of the Qumran fragments. What is told in their Enoch-collection is a myth of human hardiness, of an urge to defy and - more importantly - successfully defy the extinction of human culture. Reading the Book of Enoch as the mirror-image and prefiguration of the Book of Revelation (and thus acknowledging its eschatological meaning), this human cultural durability, enduring one relative apocalypse after another, forms an image of subversive continuity and an undermining of apocalypses that only the final and absolute Judgment Day can end.

31 1QGenesisApocryphon [1QapGen], col. XIX, 23-25; The Dead Sea Scrolls Translated, ed. García Martínez, 232. 


\section{2 ...in Chronological Religious Writings up to the Middle Ages}

Up to this point, the tale of scriptural continuity seems to be limited to the Qumran fragments and its reception in the Jewish Second Temple era, or, taking into account the The Book of Parables, early Christian times. In the following, I want to draw attention to some examples that show that the thought of subversive continuity of the Book of Watchers inspired a long durée narrative of anti-salvific subversion reaching (at least) up to the Middle Ages.

The earliest trace is again to be found in the Book of Jubilees. The story of Arpachshad, the first child born after the Flood ${ }^{32}$ and thus a symbol of the first postdiluvian generation, is told as follows:

(1) In the twenty-ninth jubilee, in the first week, in the beginning thereof Arpachshad took to himself a wife and her name was Rasu'eja, the daughter of Susan, the daughter of Elam, and she bore him a son in the third year in this week, and he called his name Kainam. (2) And the son grew, and his father taught him writing, and he went to seek for himself a place where he might seize for himself a city. (3) And he found a writing which former (generations) had carved on the rock, and he read what was thereon, and he transcribed it and sinned owing to it; for it contained the teaching of the Watchers in accordance with which they used to observe the omens of the sun and moon and stars in all the signs of heaven. (4) And he wrote it down and said nothing regarding it; for he was afraid to speak to Noah about it lest he should be angry with him on account of it. ${ }^{33}$

It is of critical importance that the rediscovery of the Watchers' heritage is combined with a story of script learning: Arpachshad, the first chanoch (teacher) of post-diluvian mankind, teaches his son Kainam, who leaves his parents to build his own city; Kainam discovers the teachings of the Watchers, most probably those his ancestor Enoch described and the Deluge had not been able to erase. Based on these words, Kainam is responsible for resurrecting a culture of sin. The latent writing carved in stone is reactivated and infects parts of the second post-diluvian generation, and Kainam must, as a conequence, hide his transcription from the eyes of his great-grandfather Noah. ${ }^{34}$ In other words, Kainam starts a subversive subculture

32 Noah sires Sem before, and Sem sires Arpachshad after the Flood (Gen. 10:21-24).

33 Jub. 4:17-18; Book of Jubilees, trans. Charles, 53.

34 Noah's insinuated hostility towards Enoch's writing could be one possible explanation for the very strange tale of Moses' destruction of the first stone panels he received on the Sinai. In Exodus 34:1 God says to Moses: "Hew thee two tables of stone like unto the first: and I will write upon these tables the words that were in the first tables, which thou brakest." The reason for the destruction of these first panels remains unclear; that Moses destroyed them because of the Israelite's apostasy is merely one possibility. Could it be that these panels were written in the wrong language, in Enoch's script, learned from the sinful Watchers? It is also possible that Moses did not dare to give this kind of ambivalent writing to his people after he saw their fickleness. This would explain why God, instead of duplicating, inscribes the plates a second time, now using the new post-diluvian script. 
that arises from the writings of the Book of Watchers - and thus proves the extent to which God's first apocalypse was undermined by the resistant power of writing.

In this case, the rediscovery of prediluvian culture is explicitly linked to sin. But later elements of the longue durée narrative lose this explicitness. In contrast, there are even narrators that seem to be eager to be affiliated with prediluvian culture. Perhaps the most important element of this diffuse tale of human continuation was written at the end of the first century CE by Flavius Josephus in his Antiquitates Iudaicae:

These [the sons of Seth], being all of virtuous character, inhabited the same country without dissension and in prosperity, meeting with no untoward incident to the day of their death; they also discovered the science of the heavenly bodies and their orderly array. Moreover, to prevent their discoveries from being lost to mankind and perishing before they became known - Adam having predicted a destruction of the universe, at one time by a violent fire and at another by a mighty deluge of water - they erected two pillars, one of brick and the other of stone, and inscribed these discoveries on both; so that, if the pillar of brick disappeared in the deluge, that of stone would remain to teach men what was graven thereon and to inform them that they had also erected one of brick. It exists to this day in the land of Seiris. ${ }^{35}$

Seth is the third child of Adam and Eve, the שֶׁת, schet (substitute) for Abel, who was murdered by Cain. His descendants, the sons of Seth, constitute the nine generations between the expulsion from Paradise and the Deluge. ${ }^{36}$ This chain of generations ends with Noah and includes Enoch. The description of the sons of Seth having "discovered the science of the heavenly bodies and their orderly array" presents the astronomical knowledge gained by Enoch on his Beyond-travels as an acquisition of the whole prediluvian lineage. Warned by Adam's prophecies, this lineage defies the God-willed erasure of their culture: they built the two pillars (one against destruction by fire, one against destruction by water) and inscribed them with the astronomical teachings, most probably those taught by the Watchers. Thus the Enochian scripture is saved for generations to come. Flavius Josephus tells us that one pillar, namely the one meant to endure a watery apocalypse, has been found in Seiris (Syria) and thus affirms that the transfer of prediluvian culture to his time was successful. In no way does he demur in this matter; in fact, he emphasises that the sons of Seth were "all of virtuous character" and that the reclamation of prediluvian culture is desirable. That means that he either does not know about the sinful nature of this former culture (which is unlikely), or that he tacitly appreciates this tale of human endurance bypassing the Deluge.

35 Flavius Josephus, Antiquitates Iudaicae, 1. 69-71; translation: Jewish Antiquities, trans. by Thackeray, 33.

36 The Torah counts nine men as Seth's descendants, each of them representing a prediluvian generation: Enos, Cainan, Mahalaleel, Jared, Enoch, Methuselah, Lamech, and Noah; see Genesis 5:132. 
In either case, his tale of cultural transmission enjoyed a revival in the high and late Middle Ages, owing mainly to its inclusion in the Aurora, a widely read Bible in Latin verse, written in the last quarter of the twelfth century by Petrus Riga. Deviating from Flavius Josephus, Petrus Riga does not ascribe the erection of the pillars to the sons of Seth. Instead, he includes the tale after having listed the seven generations descending from Cain ${ }^{37}$ (v. 455-468). Between Genesis 4:21 and Genesis 4:22, after telling of Lamech's son Iubal, who "was the father of all such as handle the harp and organ" (Gen. 4:21), Petrus Riga inserts the following:

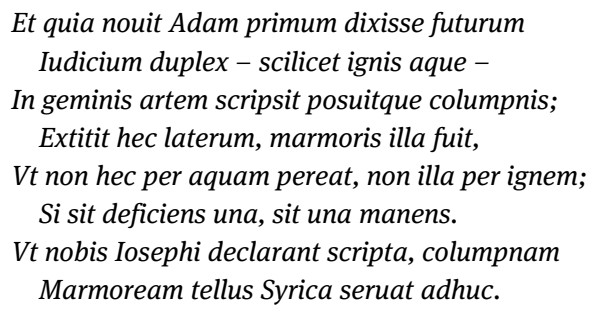

Because he [Iubal] knew that the first Adam had prophesied the coming of a twofold judgment - more precisely, by fire and by water -

he placed and wrote his art on twin pillars. One of them loomed, made of brick, the other one he made of marble, so that the one could not be worn away by water, the other not by fire, and if the one would perish, the other one would sustain.

As the writings of [Flavius] Josephus explain to us, the pillar of marble is, until nowadays, protected by the soil of Syria. ${ }^{38}$

The protagonist of these verses is no longer one of Seth's lineage but Iubal, the musician among the Cainites. He acts because of a prophecy "the first Adam" made. ${ }^{39}$ This "first" implies a second: in this case, Jesus Christ, who is - most influentially, by Augustine ${ }^{40}$ - called the "second Adam". Thereby, the implication draws parallels between Adam's prophecy of the Deluge and Jesus' prophecy of the Last Judgment (Mt. 24:1-36; Mk. 13:1-32; Lk. 21:5-36), thus emphasising the eschatological prefiguration of one apocalypse by the other. The overall result of the citation of Flavius is the incorporation of a non-biblical tale of subversive endurance into the

37 According to Genesis 4:17-24, these generations, living in the land of Nod, were: Cain, Enoch (not to be confused with the Enoch in Seth's line), Irad, Mehujael, Metusael, Lamech (also not to be confused with Noah's father). Lamech married twice: Zillah bore him a son, Tublacain, and a daughter, Naamah; Adah bore him Iabal and Iubal, the latter being the creator of the pillars in the abovecited verses.

38 Aurora Petri Rigae Biblia Versificata, ed. Beichner, v. 469-476; translation M. D.

39 Adam primum dixisse futurum could alternatively be translated as "Adam had first prophesied"; but I think that the translation above - literally - makes more sense.

40 The fourteenth chapter of De fide, spe et caritate is about Adam secundum ("the second Adam"); see Augustine, Enchiridion, trans. Mitterer, 437-443. 
text of a rhymed Bible bearing at least semi-canonical authority. To accomplish this revaluation of Flavius Josephus' tale, Petrus Riga had to change its moral implications: on the one hand, in the Jewish Antiquities, the scripture rescued from God's wrath is astronomical, most probably the words of Enoch, which should have been destroyed; on the other, the people depositing them for post-diluvian mankind are the morally sound descendants of Seth. Because of this ambivalence, Petrus Riga changes both the sender and the content of the prediluvian message. In his version, the morally corrupt Cainites worked for the preservation of their culture, and it was Iubal, the mostly harmless musician, that hid the knowledge of his art in and on the pillar. Iubal is not said to infect post-diluvian mankind with any kind of sinful writing or astronomical teachings; he only secures the continuity of his own private art instead. Thus the morally questionable tale of the resistant power of forbidden human writing is reduced to a less problematic myth of musical origin. Being deposited by one of the morally inferior Cainites, the retrieval of the prediluvian artefacts seems to be much less desirable.

This raises the question of Petrus Riga's motivation for including this tale at all. He obviously saw some value in the story he found in the Jewish Antiquities - but he also understood its dubious moral implications. As a consequence, he limited the story to a less hazardous myth, instead of excluding the element of human endurance altogether. In other words: to Petrus Riga, the statement that human culture does endure seems to have been more important than the question which elements of the old culture survived.

The tale in this form is thus embedded in a semi-authoritative Christian text, though it is now rendered morally harmless, because its original message is only completely understandable if one knows and considers its intertextual references. At the same time, the embedding facilitated the extrapolation of the story within the frame of Christian historical traditions. Only about half a century later it was revived in a comparably authoritative genre that introduced the myth to the broad audience of the German-speaking courts of the twelfth and thirteenth century: it reappears namely in Rudolf von Ems' Weltchronik. This chronicle (finished 1254) is the first German-language text depicting the world's history from its creation to the present. Rudolf von Ems includes the tale and - following his main source, the Historia Scholastica of Petrus Comestor (finished 1173) - places it in yet another setting, once again disguising its original sense, while reuniting it with its long-lost source, the tale of the Watchers.

In dirre zit begunden sehin, als wir die warheit hoeren jehin, von Seth die Gotis sun, die man, der menschen kint, die tohtern, an, die burtic warin von Cain, und gesselletin sich zouzin, so das sie an den stunden
At this time,

as we heard it truthfully said, the God-sons of Seth, the male ones, began to look at the children of mankind, the daughters, who were descended from Cain. They joined with them, so that at this time 
kindennes begunden

bi jenen dort und hie bi disin, hie wouhsin lange und groze risin ... they bore children,

there, at their place, and here, with these,

huge and mighty giants grew up. ${ }^{41}$

At first glance, Rudolf merely translates Petrus Comestor's version of the Genesis passage (Gen. 6:1-4), which reads:

Cum coepissent homines multiplicari super terram, viderunt filii Dei, id est Seth, religiosi, filias hominum, id est de stirpe Cain, et victi concupiscentia, acceperunt eas uxores, et nati sunt inde gigantes.

At the time humankind began to spread over the earth, the sons of God, these are the ones of Seth, the pious ones, looked at the daughters of men, these are the ones of Cain's tribe, and they were vanquished by desire, they took them as wives and thus the giants were born. ${ }^{42}$

The Genesis plot had already been altered in significant ways in the Historia Scholastica. For example, it is not the liaison between the Watchers of Heaven and human women that leads to the birth of the Nephilim. Instead, the descendants of Seth fall for the women of the Cainites. Although this would convert this sin into a solely human failure, Petrus Comestor still calls the sons of Seth filii Dei, and Rudolf, accordingly, Gotis sun ("sons of God"). In Genesis 6:2-3, however, this is the term used for the sinful angels. In opposition to the filii Dei, Petrus Comestor emphasises the Cainites as filias hominum, which Rudolf translates to menschen kint ("children of humankind"). These expressions are biblical, but their use here is incongruous, because the original angels/mankind encounter is now presented as a purely human affair; they thus perpetuate the idea of an angelic-human liaison, without actually adhering to the biblical version. Of course, the textual surface Rudolf adopts from the Historia Scholastica is quite transparent, given that it is at least peculiar that the liaison between two human tribes results in the birth of giants. Both passages can be described as palimpsests, in which the angels of Genesis are frailly overwritten with the Seth-tribe, allowing the former to shine through the textual surface as an ulterior foil.

However, Rudolf's palimpsest goes further than his source. In the oldest complete transmission, the Werningeroder manuscript, ${ }^{43}$ the verses describing the after-

41 Rudolfs von Ems Weltchronik, ed. Ehrismann, v. 645-654; translation M. D.

42 The Historye of the Patriarks, ed. Taguchi, 48 [translation by M. D.].

43 Rudolf von Ems' Weltchronik is preserved in over 100 fragments and complete manuscripts. There are four text families: 1. Autornahe Fassungen (versions close to the author's original text); 2. Planvolle Zusammenstellungen (systematic compilations); 3. Bearbeitungen der autornahen Fassungen (revised versions of the author's original text); 4. Free compilations. The Werningeroder is the oldest complete manuscript of the first category, written around 1300, and therefore as close as possible to the archetype of Rudolf's work. The verses quoted above differ strongly in other manuscripts and, to some extent, these changes seem to be more than just random in nature. In the beautifully illustrated Donaueschingen manuscript (writing and illustration finished 1375), for 
math of the liaison between the tribe of Seth (aka. angels) and the Cainites (aka. human females) are told using a similar technique, in this case for the purpose of including plot-elements other than those in Genesis:

\author{
sunde und suntlichir sin \\ begunde wahsen ouh an in, \\ mit kunstlichir liste kraft \\ wohs ouh ir liste meisterschaft \\ an manegir kunst und wisheit. \\ nu hat Adam in vor geseit \\ das al du welt muoste zergan \\ mit wazzir und ouh ende han \\ mit fure: fur die forhte \\ ir kunst mit vlize worhte \\ zwo sule, der eini ziegelin \\ was und du ander steinin \\ von marmil, hertir danne ein glas. \\ swaz kunst von in do fundin was \\ und irdaht, die scribin sie \\ an dise selbin sule, die \\ dise liste soltin \\ inen behabin alsi woltin, \\ so du welt und ouh du leben \\ ir chomendin ende solten geben, \\ das ir nahkomin sidir \\ die liste fundin abir widir.
}

\author{
Also, sin and sinful pursuits \\ began to increase among them. \\ By the power of skillful intellect \\ the mastery of their competences grew \\ in many arts and teachings. \\ Now, Adam had prophesised \\ that the whole world would perish \\ by water and meet its demise \\ by fire. Against this fear \\ their skill raised with diligence \\ two pillars, one made of brick \\ the other made of marble-stone, \\ that was harder than glass. \\ Whatever artistry they had invented and \\ and devised, they wrote \\ onto those pillars that should, \\ as they wished, accommodate \\ within them theses abilities, \\ so that when the world and also their lives \\ should come to an end, \\ their descendants will nevertheless \\ rediscover these abilities later. ${ }^{44}$
}

Seth's and Cain's descendants erect the pillars - a combination of Flavius Josephus' and Petrus Riga's protagonists in cooperation - but the reason Rudolf gives for mankind's sinfulness is to be found in neither source. Flavius Josephus describes the tribe of Seth as being "of virtuous character", and thus approves their act of rescuing their culture; in Petrus Riga's text, the deed is accomplished by one of the morally dubious Cainites, with the art of music withheld from God's wrath. In the Wernigeroder manuscript of the Weltchronik, we find the increasing sunde und suntlichir sin. Limited to this verse, sin could mean the mere intent to be sinful. But the textual surrounding shows that $\sin$ has to be read in its more specific Middle High German meaning of "artistic and intellectual capacity", for the following

\footnotetext{
example, the emphasis on mankind's increased intellect nourishing sin is not to be found. Instead the whole passage is abridged (or perhaps even censored) to the Genesis-compliant verses: In diesen selben iaren / wuhs an den selben luten sunden groz. / Dar in die menscheit sich sloz. / Do mit sie verdinten gotes zorn. ("In these years / great sin grew in these people. / Mankind encased itself in it. / With that they earned God's wrath”). Rudolf von Ems, "Weltchronik," Ms. Donaueschingen cod. 79, Badische Landesbibliothek Karlsruhe, https://digital.blb-karlsruhe.de/id/114092, fol. 8r. For the different manuscript families of the Weltchronik, see Walliczek, "Rudolf von Ems," 339.
}

44 Weltchronik, ed. Ehrismann, v. 677-698; translation M. D. 
verses agglomerate specified intellectual abilities and crafts (kunstlichir liste, ir liste meisterschaft, manegir kunst und wisheit, the personification of kunst in v. 686 etc.).

But neither Genesis nor the Historia Scholastica nor any of the above-mentioned sources for the pillar-plot speak of sinful skills, arts or teachings. The only text that describes intellectual increase nourishing sin is the Book of Watchers, which alone enumerates the forbidden gifts (among them scripture) given to mankind.

It is not possible to determine whether the reappearance of the Watcher-plot in Rudolf's Weltchronik is a firm intertextual link, because there is no material evidence for knowledge of this source in the European Middle Ages. ${ }^{45}$ That said, I do not underestimate the power of oral transmission and therefore the ability of narrators to deliver content from mouth to ear, from generation to generation and from culture to culture. As a result, it does seem possible that some version of the Jewish Prometheus-plot circulated in Central Europe in the thirteenth century. Interestingly, Rudolf combines this echo of the Watcher-plot with the story of the pillars. Until then, the two narrative elements had only appeared separately, and the mutual connection of both the cultural artefacts and the pillar-inscriptions to Enoch thus lay hidden. But by augmenting the pillar-myth and hinting at the teachings mankind received from the Watchers, Rudolf makes clear that "the science of the heavenly bodies" has to be an Enochian one. Rudolf lessens the sinfulness of this endurance by adopting the palimpsest-like technique he found in the Historia Scholastica, declaring the entirely human descendants of Seth to be Gotis sun, thereby transforming the angelic origin into a profane Gotteskindschaft. Furthermore, once the original sin of the Watchers is muted to a silent subtext, the sinfulness of their Promethean gifts can be included again. As a result, the story of the endurance of sinful prediluvian culture can be allowed to persist.

\section{Conclusion}

I will stop my delineation of this longue durée narrative at this point. It is, however, pertinent to ask whether this tale of endurance did itself endure beyond the Middle Ages.

First, one could point to John Dee, astronomer of Elisabeth I, who practised between 1582 and 1587 and reanimated the tale when he and his psychic medium Edward Kelly contacted angels who allowed them to bring the Enochian alphabet to earth. ${ }^{46}$ Second, one could refer to the Rosicrucians' establishment of universal ar-

45 "[O]utside Ethiopia [the] knowledge of the book largely disappeared, and it was not until the early modern period that it began once again to attract notice.” Knibb, Essays on the Book of Enoch, 21.

46 Eschner, Die Henochische Magie nach Dr. John Dee. This inspirational discovery of a universal language has echoes of Hildegard of Bingen's Lingua Ignota. The difference to Dee's alphabet is that 
cane languages that show references to the language that Enoch taught prediluvian humankind. ${ }^{47}$ One could also hint at more obscure and esoteric fin-de-siècle revivals such as the Ordo Hermeticus Aurorae, for whose esoteric practices Samuel Liddell MacGregor Mathers used Dee's Enochian alphabet. ${ }^{48}$ Later, Aleister Crowley's Thelema religion was founded on the basis of Mathers' Enochian work. ${ }^{49}$ Also, the original language that John Smith claimed to have translated for the Book of Mormon (1830), the so-called "reformed Egyptian", could easily be regarded as a branch of the Enochian script that Abram spread in North Africa: ${ }^{50}$ John Smith partook in this myth by "translating" the Book of Abraham that was written on a scroll said to also include the writings of "Enoch's Pillar, as mentioned by Josephus". ${ }^{11}$ Finally, one could even point to the US-American Church of Satan and Anton LeVey's Satanic Bible (1969), which includes a satanic version of Dee's Enochian alphabet. ${ }^{52}$

Or one could just stop here and merely assert that this tale of endurance does endure.

The more important question concerns the circumstances that enabled the endurance of a story about enduring sin, which even God failed to destroy by means of the Deluge - a twofold endurance that stands in contrast to any kind of dogmatic eschatology. Like an endlessly recurring virus, similar to the "archaic and anachronistic forms" which Jean Baudrillard describes, ${ }^{53}$ this tale repeatedly re-emerges to point out the relativity of apocalypses, and the defectiveness of God's plans to end and cleanse humankind.

there is no known connection between this secret language and Enoch or the prediluvian culture. Therefore the Lingua Ignota does not imply a deviation from God's apocalyptic plans.

47 For example, in the Confessio fraternitas Rosae Crucis from 1615 one can find the following statement referring to Adam's language and Enoch's alphabet as the lost ideals of a universal language: "Wenn wir in anderen Sprachen nicht so beredt sind, wissen wir, daß diese kein Echo der Sprache unserer Urväter Adam und Henoch darstellen, sondern vererbt sind durch die babylonische Sprachverwirrung." ("If we are not that eloquent in other languages, we know that these are not echoes of the language of our prime fathers', Adam and Enoch, but that they were inherited from the Babylonian confusion of languages."); quote in Eco, Die Suche nach der vollkommenen Sprache, 191; translation M. D.

48 Regardie, "Introduction to the Enochian System."

49 Hyatt and DuQuette, The Enochian World of Aleister Crowley. For the asserted magic of the Enochian alphabet, see Crowley, Confessions. Eine Autohagiographie, trans. Jungkurt, 1:534.

50 See the Qumran fragment 1QGenesisApocryphon in chapter II.1 of this text.

51 Larson, By His Own Hand Upon Papyrus, 82.

52 Gallagher, "Sources, Sects, and Scripture," 103.

53 Baudrillard, Die Illusion des Endes oder Der Streik der Ereignisse, trans. Voillié, 50: "Es ist unglaublich, daß nichts von dem, was man geschichtlich für überholt hielt, wirklich verschwunden ist, alles ist da, bereit zur Wiederauferstehung, alle archaischen, anachronistischen Formen sind unversehrt und zeitlos vorhanden wie Viren im Inneren des Körpers." ("It is astonishing that nothing thought to be historically outdated has really vanished. All is there, waiting for its resurrection, all archaic and anachronistic forms are unscathed and timelessly present like viruses inside the body." - translation M. D.). 
Hans Blumenberg wrote about the myth of Prometheus:

\begin{abstract}
Prometheus guarantees to men that their culture cannot be interfered with. Only he, as a Titan, could have stolen fire, not those for whose preservation he did it. [...] When one knows how to make fire, one has become resistant to divine wrath. That is why Zeus cannot reverse the theft of fire by taking it away from men, so as to keep it as the exclusive property of heaven, its place of origin. In the end nothing has changed for the gods, but everything has changed for men. Having been created by the Titans, they must reckon with the ill will of Olympian Zeus, but they have someone who has survived that ill will and prevents it from having consequences, someone whom they can count on as having tamed Zeus. ${ }^{54}$
\end{abstract}

Take this passage, replace "Prometheus" with "the Watchers", "Titans" with "angels" and "fire" with "script", and it becomes obvious: just like the antique tale of Prometheus, the abiding myth of the Watchers, as well as of their forbidden cultural gift, and its distributor Enoch, acts as the Judeo-Christian version of the testimony of humankind's ability to survive everything - even God's wrath. This tale about the origin of script is, at its core, one of a human defiance and hope so great that not even apocalypses can extinguish them.

\title{
Bibliography
}

\section{Primary Sources}

\section{Ethiopian or First Book of Enoch}

Das äthiopische Henochbuch. Translated by Siegbert Uhlig. In Jüdische Schriften aus hellenistischrömischer Zeit. Vol. 6, Apokalypsen, edited by Werner Georg Kümmel, 460-780. Gütersloh: Verlagshaus Gerd Mohn, 1984.

The Book of Enoch or 1 Enoch. Translated by Robert Henry Charles. Oxford: Clarendon Press, 1912.

Das Buch Henoch. Translated by Andreas Gottlieb Hoffmann. Jena: Croecker'sche Buchhandlung, 1833.

The Ethiopic Book of Enoch. A New Edition in the Light of the Aramaic Dead Sea Fragments. Translated by Michael A. Knibb. Oxford: Oxford University Press, 1978.

\section{Qumran Fragments}

The Books of Enoch. Aramaic fragments of Qumrân Cave 4. Edited by J. T. Milik. Oxford: Clarendon Press, 1976.

The Dead Sea Scrolls of the Hebrew University. Edited by Eleazar L. Sukenik. Jerusalem: Hebrew University Press, 1955.

54 Blumenberg, Work on Myth, trans. Wallace, 300-301. 
The Dead Sea Scrolls Study Edition. Edited by Florentino García Martínez and Eibert J. C. Tigchelaar. Leiden: Brill, 1999.

The Dead Sea Scrolls Translated. The Qumran Texts in English. Edited by Florentino García Martínez. Translated by Wilfred G. E. Watson. 2nd ed. Leiden: Brill, 1996.

Die Qumran-Essener. Die Texte vom Toten Meer. Edited and translated by Johann Maier. 3 vols.

München: Reinhardt, 1995-96.

\section{Other Sources}

Augustine. Enchiridion oder Buch vom Glauben, von der Hoffnung und von der Liebe (De fide, spe et caritate). Translated by Sigisbert Mitterer. Vol. 49/1, Bibliothek der Kirchenväter. Kempten: J. Kösel, 1925.

Bin Gorion, Micha Josef. Die Sagen der Juden. Edited by Emanuel Bin Gorion. Frankfurt am Main: Insel, 1962.

The Book of Jubilees. Translated by Robert Henry Charles. London: Society for Promoting Christian Knowledge, 1917.

Crowley, Aleister. Confessions. Eine Autohagiographie. Translated by Markus M. Jungkurt. 2 vols. Bergen a. d. Dumme: Stein der Weisen, 1986.

Flavius Josephus. Jewish Antiquities. Books I-IV. Translated by H. St. J. Thackeray. Josephus in Nine Volumes 4. Cambridge/Mass.: Harvard University Press, 1961.

Petrus Comestor. Historia Scholastica. Edited by Mayumi Taguchi. In The Historye of the Patriarks, edited from Cambridge, St. Martin's College MS G. 31 by Mayumi Taguchi, with parallel texts of the Historia Scholastica and the Bible Historale, Heidelberg 2010.

[Petrus Riga.] Aurora Petri Rigae Biblia Versificata. A Verse Commentary on the Bible. Edited by Paul E. Beichner. 2 vols. Vol. 19, Publications in Mediaeval Studies. Notre Dame: University of Notre Dame Press, 1965.

Rudolf von Ems. "Weltchronik.” Ms. Donaueschingen cod. 79, Badische Landesbibliothek Karlsruhe. https://digital.blb-karlsruhe.de/id/114092.

Rudolfs von Ems Weltchronik. Aus der Wernigeroder Handschrift. Edited by Gustav Ehrismann. Vol. 20, Deutsche Texte des Mittelalters. Berlin: Akademie Verlag, 1915.

\section{Secondary Literature}

Baudrillard, Jean. Die Illusion des Endes oder Der Streik der Ereignisse. Translated by Ronald Voillié. Berlin: Merve, 1994.

Benz, Maximilian. Gesicht und Schrift. Die Erzählung von Jenseitsreisen in Antike und Mittelalter. Quellen und Forschungen zur Literatur- und Kulturgeschichte 78. Berlin: De Gruyter, 2013.

Blumenberg, Hans. Work on Myth. Translated by Robert M. Wallace. Cambridge/Mass.: MIT Press, 1985.

Charles, Robert Henry. "Introduction." In The Book of Enoch or 1 Enoch. Translated by Robert Henry Charles, IX-CX. Oxford: Clarendon Press, 1912.

Däumer, Matthias. “'[Er] bezeugte gegen sie alle [...] - und schrieb das Ganze.' Mediale Implikationen visionärer Zeugenschaft am Beispiel des Wächterbuchs." In ÜberZeugen. Szenarien von Zeugenschaft und ihre Akteure, edited by Matthias Däumer, Aurélia Kalisky, and Heike Schlie, 49-68. München: Fink, 2017. 
Däumer, Matthias. "Vision." In Handbuch Literatur und Religion, edited by Daniel Weidner, 463467. Stuttgart: Metzler, 2017.

Dinzelbacher, Peter. Vision und Visionsliteratur im Mittelalter. Monographien zur Geschichte des Mittelalters 23. Stuttgart: Hiersemann, 1981.

Dinzelbacher, Peter."Einführung.” In Mittelalterliche Visionsliteratur. Eine Anthologie, edited by Peter Dinzelbacher, 1-35. Darmstadt: Wissenschaftliche Buchgesellschaft, 1989.

Eco, Umberto. The Search for the Perfect Language. Malden: Blackwell Publishing, 1995.

Eco, Umberto. Die Suche nach der vollkommenen Sprache. 3rd ed. München: C. H. Beck, 1995.

Eschner, Michael. Die Henochische Magie nach Dr. John Dee. 2 vols. Bergen: Kersken-Canbaz Verlag, 2000.

Gallagher, Eugene. "Sources, Sects, and Scripture. The Book of Satan in The Satanic Bible." In The Devil's Party. Satanism in Modernity, edited by Per Faxneld and Jesper Aagaard Petersen, 103122. Oxford: Oxford University Press, 2013.

Himmelfarb, Martha. Ascent to Heaven in Jewish and Christian Apocalypses. Oxford: Oxford University Press, 1993.

Hyatt, Christopher S. and Lon Milo DuQuette. The Enochian World of Aleister Crowley. 2nd ed. Tempe: Original Falcon Press, 2012.

Knibb, Michael A. "The Date of the Parables of Enoch: A Critical Review." New Testament Studies 25, no. 3 (1979): 345-359.

Knibb, Michael A. Essays on the Book of Enoch and Other Early Jewish Texts and Traditions. Vol. 22, Studia in Veteris Testamenti Pseudepigrapha. Leiden: Brill 2009.

Larson, Charles M. By His Own Hand Upon Papyrus. A New Look at the Joseph Smith Papyri. $2^{\text {nd }}$ ed. Cedar Springs: Institute of Religious Research, 1992.

Nickelsburg, George W. E. 1 Enoch 1. A Commentary on the Book of 1 Enoch. Chapters 1-36; 81-108, edited by Klaus Baltzer. Minneapolis; Augsburg Fortress Press, 2001.

Nickelsburg, George W. E. Jewish Literature Between the Bible and the Mishnah. A Historical and Literary Introduction. 2nd ed. Minneapolis: Augsburg Fortress Press, 2005.

Ranke Graves, Robert von, and Raphael Patai. Hebräische Mythologie. Reinbek: Rowohlt, 1986.

Regardie, Israel. "Introduction to the Enochian System." In The Golden Dawn. The Original Account of the Teachings, Rites, and Ceremonies of the Hermetic Order, edited by Israel Regardie, and John Michael Greer. 7th ed., 780-787. Woodbury: Llewellyn Publications, 2016.

Walliczek, Wolfgang. "Rudolf von Ems." In Die deutsche Literatur des Mittelalters. Verfasserlexikon. Vol. 8, edited by Wolfgang Stammler et al., 332-345. Berlin: De Gruyter, 1992. 